The Second International Conference on Innovations in Information Technology (IIT'05)

\title{
THE IMPACT OF TECHNOLOGICAL FACTORS ON INFORMATION SYSTEMS SUCCESS IN THE ELECTRONIC- GOVERNMENT CONTEXT
}

\author{
R. Hussein \\ Department of Information Systems, Kulliyyah of ICT, International Islamic University Malaysia, \\ Jalan Gombak, 53100, Kuala Lumpur, Malaysia. \\ ramlah@iiu.edu.my \\ H. Selamat \\ Department of Management Information Systems, Faculty of Computer Sc. \& IT, Universiti Putra \\ Malaysia, Serdang, Selangor, Malaysia. \\ N. S. Abdul Karim \\ Department of Library and Information Science, Kulliyyah of ICT, International Islamic \\ University Malaysia, Jalan Gombak, 53100, Kuala Lumpur, Malaysia. \\ shariza@iiu.edu.my
}

\begin{abstract}
Intensive research and discussion activities on the Information system success have been found to take place since the past two decades. As systems and technologies are being improved and developed, discussions on their effectiveness and evaluation on their success have been continuously debated by researchers, scholars and practitioners. Besides the major concern on IS effectiveness, factors influencing IS effectiveness are also important. Hence, this study was conducted to investigate the influence of technological factors on Delone and McLean's IS success dimension. Using a survey method, data were gathered from 201 users from four electronic government agencies in Malaysia. The technological factors were represented by IS competency, IS facilities, IS integration, IS structure and user support. The IS success dimensions used in the study were systems quality, information quality, perceived usefulness, and user satisfaction. The findings indicate that all the technological factors are significantly correlated with the four IS success dimensions. The study concludes that the technological factors investigated were very important in ensuring the successful utilization and implementation of information systems in the electronic government agencies.
\end{abstract}

Keywords: Information Systems Success, technological factor, electronic government

\section{INTRODUCTION}

The rapid growth in the use of information systems has led to several changes in the workflow of both the private and public sectors. Starting in the nineties, the public sector's conservative approach to using information systems began to change. Old and rigid systems have been replaced by the new flexible systems. The new systems have helped to overcome the problem of inefficient public service and information delivery in the public sector [1]. Following the above development, some countries including Malaysia, has begun embarking on the electronic government projects. However, the effectiveness of the electronic government system has yet to be reviewed.

In evaluating information systems effectiveness, De Lone and Mc Lean [2] proposed a comprehensive IS success model which was updated later in 2003. Their study on IS success was considered very significant in contributing towards a universal model, which many researchers 
have employed when looking at the IS performance. Attempts have also been made to validate their proposed model $[3,4,5]$. In their most current discussion of the concept, the authors pointed that there was a huge gap in the IS studies in which many researchers seem to overlook [6]. Studies in IS success have given few attention to the antecedent of the IS success. One of the important antecedent factors of IS success is the technological factor. It was envisaged that the technological factors contribute greatly to the IS success of an organization.

In addressing this research gap, we attempt to investigate the contribution of technological factors on IS success. The main objective of this study is to investigate the relationship between the technological factors and the IS success in the context of the Malaysian electronic government environment. From a comprehensive list of technological factors from related studies $[7,8,9,10,11,12,13]$, this study identified five technological factors that are potential antecedents of IS success. These factors are IS facilities, IS integration, IS competency, IS structure and user support. In addition, this study also seeks to validate the IS success model in the electronic government setting.

\section{RESEARCH FRAMEWORK AND HYPOTHESES}

Despite the availability of other models [8,15], this study adapted De Lone \& Mc Lean's [2] model to represent the IS success construct. The model was chosen due to its strength in validity and reliability through continuous validation made in many studies. The model had been found to be the most reliable and appropriate for this study. Since its establishment in 1992, more than 200 studies have been reported to cite and test this model [6]. The authors proposed six dimensions of success as the dependent variables - system quality, information quality, system use, user satisfaction, individual impact and organizational impact. Seddon [16] extended DeLone $\&$ McLean's [2] model by replacing IS use into benefits of use. The author used perceived usefulness construct to substitute De Lone \& Mc Lean's IS use construct. This study adopts Seddon's perceived usefulness as an IS success measure replacing system use as in the De Lone \& Mc Lean's model.

Consequently, based on the up-stream portion of DeLone \& McLean's [2] model, a research framework as shown in Figure 1 is developed. From the framework, five hypotheses were developed. The relationships between the technological factors investigated, namely; IS facilities, IS competency, IS integration, user support and IS structure, and the four dimensions of IS success; system quality, information quality, perceived usefulness and user satisfaction, are shown in the framework (Figure 1).

\subsection{IS Facilities}

IS facilities refer to the availability of IS/IT resources and IS/IT infrastructure that are provided during any IS project implementation. Infrastructural facilities were found to be positively related with IS success and adoption [8]. In an empirical study by Grover [8], IS infrastructure was found to be one of the top predictors of IS success among several factors investigated. In a later study, Wixom \& Watson [17] found that the technology used for development was associated with technical implementation success. 
The Second International Conference on Innovations in Information Technology (IIT'05)

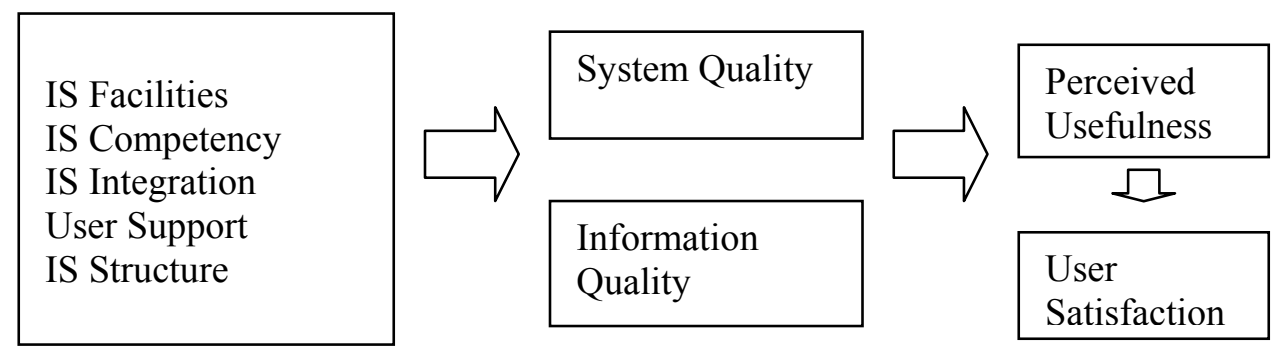

Figure 1 The Research Framework

Byrd, Sambamurthy \& Zmud [18] defined IT infrastructure as the shared information services delivery base within an organization that is built around information technologies and a specific body of knowledge such as skills and experience. The authors used IT innovativeness and IT sophistication to operationalize the IT infrastructure and found that large agencies with mature IT infrastructures were better able to develop higher quality IT plans. In a recent study by Zhu et al. [19], they found that physical IT infrastructure contributed to e-business adoption in European firms. The study undertakes the view that provision of sufficient and good facilities in any electronic government project implementation will result in implementation success. Thus, the above discussion leads to the first hypothesis.

H1. IS facilities is positively associated with the IS success dimensions.

\subsection{IS Competency}

According to Whyte \& Bytheway [11], IS competency refers to the degree to which project staff possesses the required skills and knowledge in order to perform the required services. The authors found IS competency among the significant attributes of IS success. Previous studies had indicated that IS competency was found to be one of the top ten dimensions for assessing IS function performance [20].

Byrd and Turner[21] found that organizations with a team of highly technical staff tend to have better IT infrastructure flexibility, and at the same time are able to increase the organization's competitive advantage in key business management areas. In another study, Byrd and Davidson [22] found that IT department technical quality which includes staff competency, had an influence on IT impact on the supply chain that leads to the firm's performance. From the above, we believe that, the IS competency factor is one of the important technological factor that would influence IS success. Thus, hypothesis 2 was developed.

H2. IS competency is positively associated with the IS success dimensions.

\subsection{IS Integration}

IS integration refers to the degree to which different systems are integrated in terms of data, functionality and appearance [11]. According to Saunders \& Jones[20], integration refers to the integration of technologies across other organizational units. They added that IS integration is needed to ensure a smooth and cost-effective flow of information across all business functions. The authors found that IS integration is among the top-ten dimensions of IS function performance assessment. However, Grover [8] did not find significant support for IS integration in influencing IT adoption. 
In a related development, a study on key issues in the IS management of ten nations, Watson et al. [23] found technology integration ranked the eighth most important issue among the top ten common issues identified. Bhatt [24] found significant effects of data integration and communication network integration on process improvement initiatives and customer focus in Fortune 500 US firms. The above discussion suggests that IS integration is an important factor in electronic government implementation success. Thus, hypothesis 3 was developed as follows.

H3. IS integration is positively associated with IS success dimensions.

\subsection{User Support}

User support deals with the technical support and help given to users in terms of operating the information systems in the organization. The importance of user support to the success of user computing has been highlighted in many studies [25,26,27,28]. Many researchers found significant support for the relationship between personal computing success and user support $[29,30,31]$. In the electronic government working environment, we believe that technical support to users of the systems is crucial. Users will most likely seek help in using the systems in their daily operations. Thus, from here, hypothesis 4 was developed as follows.

H4. User support is positively associated with IS success dimensions.

\subsection{IS Structure}

IS structure refers to the extent to which the information systems are structured or dispersed throughout an organization. Allen \& Boynton[32] and Boynton et al.[33] pointed that, the extent of IS structure can be assessed by the existence of centralized computing structures, the dissemination of personal and mini computers, or the use of network technologies. Ang et al.[13] found that organizations with a distributed structure of IT facilities are associated to IT usage. The author found that a decentralized IS structure has more influence on IT use than a centralized IS structure. But, other researchers found a centralized IS structure tend to promote efficiency and effectiveness. The study undertakes the view that IS structure, distributed or centralized will influence system success. Thus, the last hypothesis was developed as follows.

H5. IS Structure is positively associated with IS success dimensions.

\section{METHODOLOGY}

\subsection{Population and Sample}

The population of this study consisted of employees of the electronic government agencies in Malaysia. Four electronic government agencies from the central administration complex in Putrajaya were selected. The agencies were selected based on them being the pilot or pioneer agencies in implementing the electronic government systems applications. Prior to the actual field survey, initial visits to the selected agencies and meetings with higher authorities at the agencies were conducted. A sampling frame was acquired which comprised current lists of employees from the agencies selected. Subjects for this study were then chosen using a stratified random sampling based on their position level. Only employees using an information system in their work were included in the samples. From the sampling frames of the four agencies, a total of 450 subjects were chosen as samples. The sample size was acquired from the table of Krejcie \& Morgan[34] that simplified the sample size decision in order to ensure a good decision model. 


\subsection{Measures}

The study used perceptual measures to capture data on IS success and technological factors. Perceptual measures are acceptable measures in most survey research. In most of the questions, a six-point Likert-scale was used to represent the responses of the subjects. The forced-choice scale was adopted in the study to overcome the problem of 'not sure' or 'don't know' responses [35]. The forced-choice scale was also used to overcome the problem of too many neutral responses, which are common among Asian people when given the option to choose.

Based on De Lone \& Mc Lean's recommendations, the study adapted validated measures from related studies on IS success. Five items from Doll \& Tokzadeh's [36] and Davis's [37] were used to operationalize System Quality. Nine items from Doll \& Tokzadeh [36] were used to operationalize information quality. Doll \& Tokzadeh's instruments were acceptable measures and had been validated by other researchers (Seddon \& Kiew [3]). Four items from Seddon \& Yip [38] were used to operationalize overall satisfaction towards the system. Items from Davis [37] were used to measure perceived usefulness.

Demographic factors including age, gender, educational level, job level, departmental level, length of service were also measured. A single item measure was used for each of the technological factors. Using a six-point Likert scale ranging from $1=$ strongly disagree to $6=$ strongly agree. Measures were adapted from Ang et al.[13].

\subsection{Data Collection}

The study used a self-administered questionnaire to measure the system quality, information quality, perceived usefulness, and user satisfaction. A pre-test was conducted prior to the pilot study. Following the pre-test exercise, a modified questionnaire was developed and a pilot study was conducted. The pilot study was carried out in three public agencies in Putrajaya. Ten questionnaires were distributed to each agency. Twenty questionnaires were collected and they were found reliable. Prior to the actual fieldwork, the questionnaires were refined and rephrased accordingly. The questionnaires were also translated to the native language (Malay) to cater for the lower job level group such as the clerical and the administrative support staff who were not that conversant in English.

The modified questionnaires were then distributed to employees of the selected agencies. A total of 450 questionnaires were distributed, and 201 were returned giving a $45 \%$ response rate. Users came from a range of functional areas background including Administrative, Finance and Human resource $(38.7 \%)$, IT related functions $(37.7 \%)$ and other areas $(23.6 \%)$. Reliability tests were conducted and the results were as follows (perceived usefulness, 0.96; system quality, 0.92; information quality, 0.94; user satisfaction, 0.94; technological factors, 0.86).

\section{RESULTS AND DISCUSSIONS}

\subsection{Respondents' Profile}

About two thirds of the respondents (62.4\%) were between 20-39 years old, followed by (37.6\%), who were more than 40 years old. Slightly more than half of the respondents $(55.8 \%)$ were 
female. Majority of the respondents (66.8\%) had a Diploma certificate or higher, followed by those (33.2\%) having lower educational background.

Majority of the respondents $(59.1 \%)$ held executive posts or higher. This proportion includes professionals, middle-level managers and top-level managers from various fields. The support staff $(40.9 \%)$ made up the rest of the respondents. Those were the users involved in administrative and technical support services in the agencies concerned.

More than half of the respondents $(60.9 \%)$ had served the government for six years or more, this includes $21 \%$ of the respondents who had served the government for more than twenty years. The remaining respondents $(39.1 \%)$ had served the government for five years or less. These figures show that the majority of the respondents had served the government long enough and this justifies their evaluations towards the information systems used by the government agencies concerned.

\subsection{IS Success Factors}

The association between the four IS success dimensions employed in the study, perceived usefulness, information quality, system quality and user satisfaction are presented in Table 1. Using correlation analysis, the results show that the four variables are moderately and highly correlated with one another. The highest correlation value was between perceived usefulness and information quality. The cutoff value for highly correlated factors is 0.7 as suggested by Bryman $\&$ Cramer [39]. The correlation value suggests the four IS success dimensions are significantly related with each other. This findings are consistent with previous studies on relationship between the four IS success factors [3,5].

Table 1 Correlation Analysis Between IS Success Factors

\begin{tabular}{|c|c|c|c|c|}
\hline Items & $\begin{array}{l}\text { Perceived } \\
\text { Usefulness }\end{array}$ & $\begin{array}{l}\text { Information } \\
\text { Quality }\end{array}$ & $\begin{array}{l}\text { System } \\
\text { Quality }\end{array}$ & $\begin{array}{l}\text { User } \\
\text { Satisfaction }\end{array}$ \\
\hline Perceived Usefulness & 1.000 & & & \\
\hline Information Quality & $.788 * *$ & 1.000 & & \\
\hline System Quality & $.750 * *$ & $.677^{* *}$ & 1.000 & \\
\hline User Satisfaction & $.705 * *$ & $.669^{* *}$ & $.619^{* *}$ & 1.000 \\
\hline
\end{tabular}

\subsection{Technological Factors and IS Success}

The main objective of the study was to investigate the relationship between the technological factors and IS success factors. As noted previously, five technological factors have been identified to be included in the study. The factors are IS facilities, IS competency, IS structure, IS integration and user support. Table 2 shows the relationship between the technological factors and the four IS success dimension. A summated scale of IS success was calculated by averaging the mean of the four IS success dimensions of the study. Correlation analysis was run on the data using SPSS version 11. The results show that the technological factors are significantly correlated with the IS success factors and the IS success summated variate.

The results of the relationship supported all the hypotheses developed in the study. Hypothesis H1 was supported indicating a positive relationship between IS facilities and IS success. The 
findings are consistent with other studies [7,20,8,10,11]). However, this finding did not support the study done by Ang et al.[13]. The outcome suggests that availability of hardware and software resources has significant impact on system success.

The second hypothesis $\mathrm{H} 2$ was also supported, it implies that a higher level of IS competency relates to a higher degree of satisfaction in system quality, information quality, system quality and overall user satisfaction. The results are incongruent with previous study by Ang et al.[13], however, the findings are consistent with other related studies $[7,11,10,20])$. The results suggest that having competent in-house IS personnel are crucial to ensure systems implementation success. This is because, the IS personnel are expected to have the appropriate skills and expertise to resolve the technological issues faced by the end users.

Table 2: Correlation Analysis between Technological Variables and IS Success Dimensions

\begin{tabular}{lrrrrr}
\hline & $\begin{array}{c}\text { Perceived } \\
\text { Usefulness }\end{array}$ & \multicolumn{2}{c}{$\begin{array}{l}\text { Information } \\
\text { Quality }\end{array}$} & $\begin{array}{l}\text { System } \\
\text { Quality }\end{array}$ & $\begin{array}{l}\text { Overall } \\
\text { Satisfaction Success }\end{array}$ \\
\hline Items facilities & $.575^{* *}$ & $.620^{* *}$ & $.528^{* *}$ & $.645^{* *}$ & $.672^{* *}$ \\
User Support & $.525^{* *}$ & $.540^{* *}$ & $.496^{* *}$ & $.629^{* *}$ & $.625^{* *}$ \\
IS Integration & $.505^{* *}$ & $.587^{* *}$ & $.529^{* *}$ & $.644^{* *}$ & $.642^{* *}$ \\
IS Structure & $.288^{* *}$ & $.305^{* *}$ & $.334^{* *}$ & $.313^{* *}$ & $.336^{* *}$ \\
IS Competency & $.577^{* *}$ & $.643^{* *}$ & $.548^{* *}$ & $.618^{* *}$ & $.675^{* *}$ \\
\hline
\end{tabular}

** Correlation is significant at the 0.01 level (2-tailed)

The results also supported hypothesis H3, implying higher level of IS integration correlates to higher levels of perception towards the four IS success dimensions. The results are consistent with studies by Saunders \& Jones [20] and Whyte \& Bytheway [11]. The evidence may suggest that a well-integrated electronic government (EG) system is critical in systems success.

Hypothesis H4 was supported; it indicates that user support is positively related to IS success dimensions. The findings are consistent with studies by Mirani \& King[29]; Vijayaraman \& Ramakrishna[30]; Bergeron et al.[31]; Buyukkurt \& Vass[27]; and Igbaria \& Zinatelli[28]. The positive outcome may be due to the implementation of the electronic government systems that needs to be maintained, monitored and supported from time to time.

The last hypothesis H5 was also supported. The results imply that a decentralized IS structure is partially related to system quality, information quality, perceived usefulness and user satisfaction. The low correlation values indicate that a decentralized IS structure is less likely relate to the IS success dimensions. In another word, centralized IS structure is preferred over a decentralized IS structure. This may be due to the nature of the public sector environment which adopts the traditional style of centralized IS structure.

Further analyses using a stepwise regression analysis, results in IS facilities (beta $=0.318$ ) and IS competency (beta $=0.318$ ) as the two highest predictors of IS success, followed by IS integration (beta $=0.210$ ). This suggests that the three factors, IS competency, IS facilities and IS integration were dominant technological factors in influencing IS success. 


\section{CONCLUSION}

In short, it is clear that the significant relationship between the technological factors investigated and IS success dimensions evidently suggests the importance of the five factors in ensuring successful information systems. The empirical evidence also supports the impact of technological factors that act as the antecedent factors in influencing IS success. Consequently, the study adds to the literature on technological factors influencing IS success that needs more emphasis. Furthermore, the study found strong support on the relationship between the IS success dimensions as proposed by DeLone \& McLean's [2].

To generalize, the findings of the study showed the importance of technological factors in determining the effectiveness of IS applications in the electronic government agencies in particular and the public sector in general. Consequently, this study sends a strong message to policy makers and public managers to provide adequate IS facilities and system accessibility, and a well-developed system integration in order to facilitate IS success. Another key factor that relates to the technological imperative includes the competency of IS staff. The public managers must ensure that they have a competent IS staff in order to help them handle the sophisticated and complex systems used in the public sector. In order to achieve this, they need to motivate their staff in using the systems and also provide the necessary training.

In conclusion, this study is not without limitation. Besides, investigating technological factors, other criteria influencing success may also need to be examined. Features, such as organizational factors and external factors are equally important in promoting success in the organizations. Future studies should consider these attributes in order to look at success in a more meaningful way. Further research should also look into the empirical studies on net benefits of IS success as included in Seddon [16] and De Lone \& Mc Lean [6] models. Finally, this study was conducted in an electronic government setting; hence, future studies should consider other sets of environment.

\section{ACKNOWLEDGEMENT}

The authors wish to acknowledge Rozina Abdul Ghani from the English Language Division of CELPAD, IIUM for her support in editing this paper.

\section{REFERENCES}

[1] Seneviratne, J.S. (1999) Information Technology and Organizational Change in the Public Sector, In Idea Group Publishing, Applications in Public Administration: Issues and Trends, Hershey, USA.

[2] DeLone, W.H. \& McLean, E.R. (1992). Information Systems Success: The Quest for the Dependent Variable. Information Systems Research, 3(1), 60-90.

[3] Seddon, P.B. \& Kiew, M.Y. (1994). A Partial Test and Development of the DeLone and McLean model of IS Success. Proceedings of the International Conference on Information Systems, Vancouver,BC, Canada (ICIS 94), 99-110.

[4] Almutairie, H. (2001), Evaluating Information Systems Success in Public Organizations: A Theoretical Model and Empirical Validation. Unpublished doctoral dissertation, The Pennsylvania State University.

[5] Rai, A., Lang, S.S., Welker, R.B. (2002). Assessing the validity of IS success models: An Empirical test and Theoretical analysis. Information Systems Research, 13(1), 50-69. 
The Second International Conference on Innovations in Information Technology (IIT'05)

[6] DeLone, W.H. \& McLean, E.R. (2003). The DeLone and McLean Model of Information Systems Success: A Ten-Year Update. Journal of Management Information Systems,, 19(4), 9-30.

[7] Cahill, A.G., Stevens, J.M. , LaPlante, J.M. (1990). The utilization of information systems technology and its impact on organizational decision-making. Knowledge: Creation, Diffusion, Utilization 12 (1), 53-79.

[8] Grover, V. (1993). An empirically derived model for the adoption of customer-based interorganizational systems. Decision Sciences, 24(3), 603-639.

[9] Caudle, S.L., Gorr, W.L., \& Newcomer, K.E.(1991). Key Information Management Issues for the public sector. MIS Quarterly, 15(2), 171-188.

[10] King, W.R., Teo, T.S.H., 1994. Facilitators and inhibitors for the strategic use of Information Technology. Information \& Management, 27, 71-87.

[11] Whyte, G. \& Bytheway, A. (1996). Factors affecting information systems' success. International Journal of Service Industry Management, 7(1), 74-93.

[12] Tallon, P.P., Kraemer, K.L., \& Gurbaxani, V. (2000). Executives' Perceptions of the business value of information technology: A process-oriented approach. Journal of Management Information Systems, 16(4), 145-173.

[13] Ang, C.L., Davies, M.A., Finlay, P.N. (2001), An empirical Model of IT usage in the Malaysian Public Sector. Journal of Strategic Information Systems, 10, 159-174.

[14] Hair, J., Anderson, R., Tatham R., and Black, W.(1998), Multivariate Data Analysis, Fifth Edition, Prentice Hall, New Jersey.

[15] Salleh, Y, \& Alshawi, M. (2005). An alternative model for measuring the success of IS projects: the GPIS model. Journal of Enterprise Information Management, 18(1), 47-63.

[16] Seddon, P.B. (1997). A Respecification and Extension of the DeLone and McLean Model of IS Success. Information Systems Research, 8(3), 240-253.

[17] Wixom, B. and Watson, H. (2001), An Empirical Investigation Of the Factors Affecting Data Warehousing Success. MIS Quarterly, 25(1), 17-32.

[18] Byrd, T. A., Sambamurthy, V., \& Zmud, R.W. (1995). An examination of IT planning in a large, diversified public organization. Decision Sciences, 26(1), 49-73.

[19] Zhu, K., Kraemer, K. \& Xu, S. (2003). E-Business Adoption by European Firms: A CrossCountry Assessment of the Facilitators and Inhibitors. European Journal of Information Systems (EJIS), 12 (4), 251-268

[20] Saunders, C.S. \& Jones, J.W. (1992). Measuring Performance of the Information Systems Function. Journal of Management Information Systems, 8(4), 63-73.

[21] Byrd, T.A. \& Turner, E.D. (2001). Measuring the Flexibility of Information TechnologyInfrastructure. Journal of Management Information Systems, 17(1), 167-208.

[22] Byrd, T.A. \& Davidson, N.W. (2003). Examining possible antecedents of IT impact on the supply chain and its effect on firm performance. Information Management, 41(2), 243-255

[23] Watson, R.T., Kelly, G.G., Galliers, R.D. \& Brancheau, J.C. (1997). Key issues in Information systems management: An international perspective. Journal of Management Information System, 13(4), 91-115.

[24] Bhatt G. (2000). An empirical examination of the effects of information systems integration on business process improvement. International Journal of Operations \& Production Management, 20 (11 \& 12): 1331-1359

[25] Amoroso, D.L. (1988). Organizational issues of end-user computing. Database, 19(3), 49-58.

[26] Amoroso, D.L., \& Cheney, P.H. (1991). Testing a causal model of end-user application effectiveness. Journal of Management Information Systems, 8(1), 63-89.

[27] Buyukkurt, M.D. \& Vass, E.C. (1993) Investigation of factors contributing to satisfaction with end-user computing process. Canadian Journal of Administtration Sciences, 10(3),212-228. 
[28] Igbaria, M., Zinatelli, N.; Cragg, P. and Cavaye, A. (1997). Personal Computing acceptance factors on small firms. MIS Quarterly, 21 (3), 279-302

[29] Mirani, R., \& King, W.R. (1994). Impacts of end-user and information center characteristics on end-user computing. Journal of Management Information Systems, 11(1), 141-166.

[30] Vijayaraman, B.S., \& Ramakrishna, H.V. (1990). A comparative analysis of successful and unsuccessful information centers. Information \& Management, 19(3), 199-209.

[31] Bergeron, F., Rivard, S. \& DeSerre, L. (1990). Investigating the support role of the information center. MIS Quarterly, 14(1), 247-260.

[32] Allen, B. \& Boynton, A.C. (1991). Information architecture in search of efficient Flexibility. MIS Quarterly, 15, 435-445.

[33] Boynton, A.C., Zmud, R.W., Jacobs, G.C. (1992). Whose responsibility is IT Management. Sloan Management Review, 33(4), 32-38.

[34] Krejcie, R. \& Morgan, D. (1970). Determining sample size for research activities. Educational \& psychological measurement. 30, 607-610

[35] Zikmund, W. (2003). Business Research Methods ( $7^{\text {th }}$ Ed.). Ohio: Thomson Learning

[36] Doll, W.J. \& Tokzadeh, G. (1988). The measurement of End-User Computing Satisfaction. MIS Quarterly, 12(2), 258-274.

[37] Davis, F.D. (1989). Perceived Usefulness, Perceived Ease of Use, and User Acceptance of Information Technology. MIS Quarterly, 13(3), 319-340.

[38] Seddon, P. \& Yip, S.K. (1992). An Empirical Evaluation of User Information Satisfaction (UIS) Measures for Use with General Ledger Account Software. Journal Of Information Systems, 5, 75-92.

[39] Bryman, A. and Cramer, D. (2001). Quantitative Data Analysis with SPSS Release 10 for Windows: A Guide for Social Scientists. London: Routledge. 